\title{
Progesterone receptor signaling in the normal breast and its implications for cancer
}

\author{
Cathrin Brisken ${ }^{1,2}$ and Valentina Scabia1 \\ 1ISREC - Swiss Institute for Experimental Cancer Research, School of Life Sciences, Ecole Polytechnique Fédérale de Lausanne (EPFL), Station 19, \\ Lausanne, Switzerland \\ 2Breast Cancer Now Research Centre, Institute of Cancer Research, London, UK
}

Correspondence should be addressed to C Brisken: cathrin.brisken@epfl.ch

This review forms part of a special section on 90 years of progesterone. The guest editors for this section are Dr Simak Ali, Imperial College London, UK and Dr Bert W O'Malley, Baylor College of Medicine, USA

\begin{abstract}
Progesterone is considered as the pregnancy hormone and acts on many different target tissues. Progesterone receptor (PR) signaling is important for normal development and the physiologic function of the breast and impinges on breast carcinogenesis. Both systemically and locally, in the breast epithelium, there are multiple layers of complexity to progesterone action, many of which have been revealed through experiments in mice. The hormone acts via its receptor expressed in a subset of cells, the sensor cells, in the breast epithelium with different signaling outcomes in individual cells eliciting distinct cellintrinsic and paracrine signaling involving different mediators for different intercellular interactions. PR expression itself is developmentally regulated and the biological outcome of PR signaling depends on the developmental stage of the mammary gland and the endocrine context. During both puberty and adulthood PR activates stem and progenitor cells through Wnt4-driven activation of the myoepithelium with downstream Adamts18induced changes in extracellualr matrix (ECM) / basal membrane (BM). During estrous cycling and pregnancy, the hormone drives a major cell expansion through Rankl. At all stages, PR signaling is closely tied to estrogen receptor $\alpha(E R)$ signaling. As the PR itself is a target gene of ER, the complex interactions are experimentally difficult to dissect and still poorly understood. Ex vivo models of the human breast and studies on biopsy samples show that major signaling axes are conserved across species. New intraductal xenograft models hold promise to provide a better understanding of PR signaling in the normal breast epithelium and in breast cancer development in the near future.
\end{abstract}
Key Words
- stem cells
- cell proliferation
- mammary gland development
- breast carcinogenesis
- Rankl
- Wnt4
- Adamts18

\section{Introduction}

A woman's risk to get breast cancer is affected by her reproductive history and hence exposure to reproductive hormones. An early full-term pregnancy has protective effects (MacMahon et al., 1970), whereas risk increases with the number of menstrual cycles she experiences during her life time, that is with shorter cycles, younger age at menarche, and later menopause (Colditz et al., 2004). Furthermore, exposure to exogenous hormones, as it occurs widely in the context of hormonal contraception and hormone replacement therapy, increases breast 
cancer risk. Finally, exposures to endocrine disruptors, in particular when they occur in utero and during the perinatal period, affect breast cancer risk, as reviewed in (Soto \& Sonnenschein, 2015; Soto et al., 2013).

The role of the ovarian steroid, progesterone, is tightly linked to ER signaling and is just beginning to emerge from the shadow of its highly visible cousin 17- $\beta$-estradiol (Brisken, 2013). What we know about PR signaling in the normal breast and how this relates to breast carcinogenesis, will be examined here in its broader developmental and physiological context.

The particular sensitivity of the breast to carcinogenic insults is likely a consequence of its unique plasticity: the breast is the only organ that develops mostly after birth and can undergo repeated cycles of cell proliferation and differentiation during pregnancy without exhaustion. The two major ovarian hormones, estrogens and progesterone, have important roles in orchestrating morphogenesis, cell proliferation and differentiation at different stages of development to ensure that the breast can produce copious amounts of milk for the offspring by the end of pregnancy.

To dissect the role of PR signaling in normal development and physiology, rodent models, in particular genetically engineered mouse models (GEMMs), have been instrumental. What we have learnt from these models and how these findings translate to human breast function and human breast cancer development will be discussed here.

\section{Development and physiology of the breast}

The hypothalamic-pituitary-ovarian axis controls female reproductive function and the development and physiology of the breast. The hypothalamic-pituitary clock determines the onset of puberty and the pituitary peptide hormones, LH and FSH, control ovarian function. The ovaries are the major source of estrogens and progesterone of which they secrete only trace amounts until puberty.

The breast is a skin appendage that develops through epithelial-mesenchymal interactions in the embryo (Veltmaat, 2017). At birth, rudimentary glandular tissue emanates from the nipples. This small gland grows isometrically with the rest of the body until puberty. The budding of the breasts, thelarche, heralds puberty and coincides with increased ovarian estrogen (E) and some progesterone $(\mathrm{P})$ production. When sexual maturity is reached and ovulatory menstrual cycles are established, cyclical changes in hormone levels are established (Fig. 1) with an estrogen peak occurring in the first half of the cycle, prior to ovulation, and a raise in progesterone during the second phase (luteal phase) that is accompanied by a less-pronounced increase in estrogen levels and elevated testosterone levels (Skiba et al., 2019). When the egg is fertilized and implants, the corpus luteum will produce increasing levels of progesterone that will be further increased through placental progesterone production (Fig. 1). If the egg is not fertilized, progesterone levels drop abruptly, menstrual bleeding occurs, and the next menstrual cycle begins.

Extensive longitudinal growth of the ducts with branching and expansion of the mammary fat occur during puberty. In the adult female, recurrent menstrual cycles elicit changes within the breast. Women may feel breasts engorge due to increased blood flow and subtle

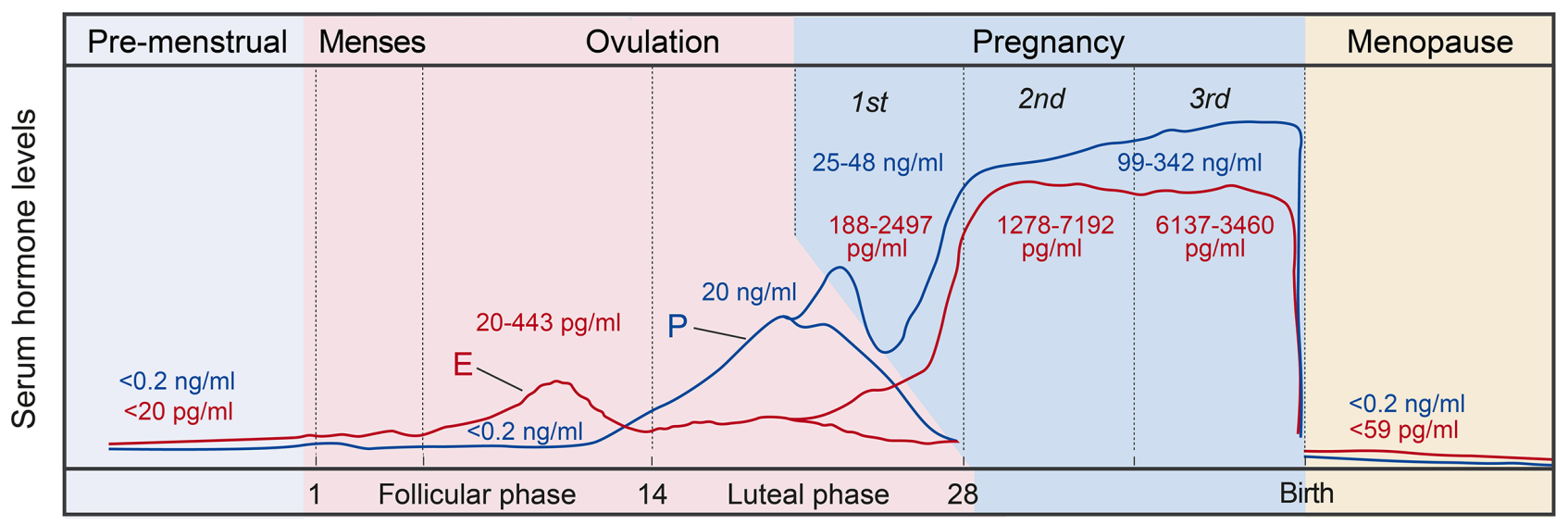

Figure 1

Schema of hormonal changes during a woman's life cycle. Scheme showing the plasma concentrations of the two ovarian hormones $\mathrm{E}$ (red) and P (blue) over the lifetime of a woman as a function of reproductive stage of a woman. Data are based on studies on puberty (Elmlinger et al., 2005), during menstrual cycle, menopause (Kratz et al., 2004) and in pregnancy (Abbassi-Ghanavati et al., 2009). 
changes in epithelial cell morphology can be observed. The myoepithelium becomes more prominent, the ECM is distended (Vogel et al., 1981). Mitotic figures can be observed in the luminal epithelium during luteal, whereas the breast is quiescent during follicular phase (Anderson et al., 1982; Ferguson \& Anderson, 1981). Breast epithelial cell proliferation culminates during early and midpregnancy, driving further branching and alveologenesis thereby achieving an enormous increase in functional surface. Following differentiation into a milk-secreting organ, copious amounts of milk can be produced during lactation. Upon weaning, milk production stops and most of the epithelial structures disappear. No matter how many pregnancies occur, there is no evidence that the cell expansion potential of the breast epithelium gets exhausted. This process of extensive cell proliferation prior to lactogenic differentiation is largely stimulated by PR signaling as we will explain below.

\section{PR signaling in the normal breast}

Detailed insights into the complexities of PR signaling at the molecular level have been gained from studies with T47D cells, a breast cancer cell line established from the pleural effusion of a 54-year-old breast cancer patient (Keydar et al., 1979) and several other hormone-sensitive breast cancer cell line models, such as MCF-7 and ZR-75 cells, and this work is reviewed elsewhere in this issue.

It has become apparent that PR signaling is context dependent and that, in particular, growth factor receptor signaling and cell cycle kinases intersect with it at multiple levels (Dwyer et al., 2020; Hagan \& Lange, 2014). As tumor cells have increased growth factor receptor signaling activity, the context in which progesterone will act in a cancer cell is likely very different from that of a normal breast epithelial cell and it is unclear how representative findings in any cell line are for what happens in different patients' tumors.

Another major obstacle to our understanding of physiological PR signaling is the lack of cell line models for normal breast epithelial cells that are hormone responsive. Primary breast epithelial cells can be readily obtained from reduction mammoplasty specimens (Stampfer \& Bartley, 1985) but as soon as they are cultured in vitro, they lose hormone receptor expression. Moreover, upon passaging primary human breast epithelial cell cultures, which contain a mix of luminal and myoepithelial cells, the luminal cells, which proliferate more slowly in vitro, are lost and cells with a basal phenotype, DNp63+, ITGB1+ grow out.
As a consequence, all immortalized HBEC cells lines and so-called normal breast cell lines, like MCF10A, represent a basal phenotype and have no hormone receptor expression.

The use of 3D cultures with matrigel has demonstrated the importance of the correct structure in space and the role of the extracellular matrix (ECM) for the formation of a bi-layered epithelium and cellular differentiation (Aggeler et al., 1991), however, steroid hormone receptor expression is down modulated and progesterone target genes like WNT4 and RANKL are not induced (Graham et al., 2009). Nevertheless, in these various elegant systems differential effects on the ECM (Liu et al., 2018) and on cell proliferation (Graham et al., 2009; Sokol et al., 2016) have been observed in response to hormone stimulation. In light of the complexities in vivo with changing hormone levels, hormones acting on many different tissues with many indirect effects on the breast, it has been a challenge to dissect the mechanisms of PR signaling in the breast epithelium.

\section{Hormone ablation and replacement studies in rodents}

The foundations of our understanding of the endocrine regulation of the mammary gland were laid in the late 1950s by hormone ablation and replacement experiments performed in rats, rabbits, and mice (Lyons, 1958; Nandi, 1958). Through surgical removal of the pituitary gland, the ovaries and the adrenal glands, animals were hormone depleted, and as a result, mammary gland development stalled and the epithelium atrophied. In the tripleabrogated animals, mammary gland growth was largely restored by injection of growth hormone (GH), E, and P. In the presence of $\mathrm{GH}$, administration of $\mathrm{E}$ was sufficient to trigger the ductal outgrowth with characteristic terminal end buds and dichotomous branching that is seen during puberty (Fig. 2). Progesterone had little effect in the absence of circulating estrogens, which may, at least in part, be due to very reduced expression of the PR, which is an ER target gene (Haslam \& Shyamala, 1979; Kastner et al., 1990). Added to GH, E+P treatment resulted in extensive ductal side branching and alveolar bud formation driving the gland to a mid/late pregnancy-like state (Fig. 2). These experiments established $\mathrm{P}$ as driver of side branching and begged the question whether the changes elicited by hormone administration are attributable to PR signaling in the mammary gland and if so, in which cell type, or secondary to signals from other organs. 


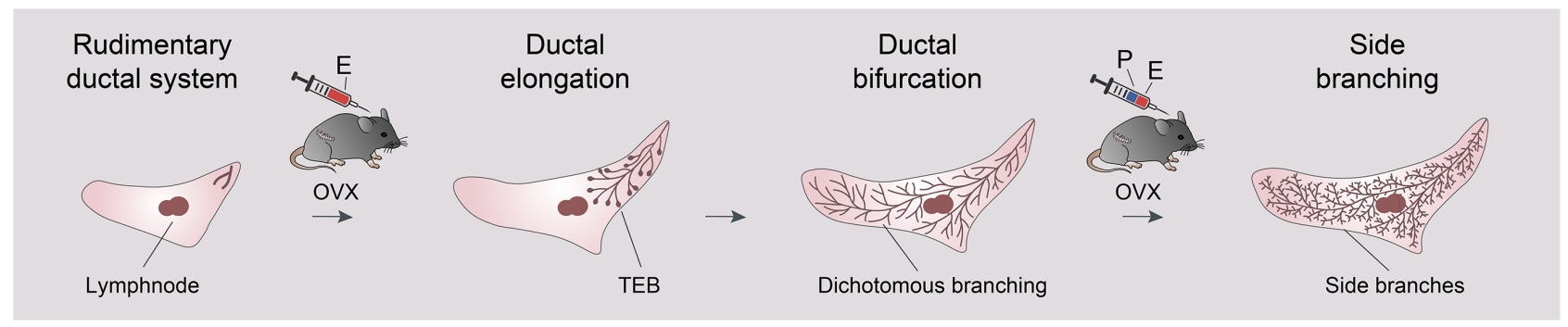

Figure 2

Hormone-induced changes in the mouse mammary gland. Scheme depicting the morphogenetic changes elicited by $\mathrm{E}$ and $\mathrm{E}+\mathrm{P}$ administration in mice ovariectomized in this case just around puberty. The rudimentary ductal system present at birth is induced to branch dichotomously. At the tips of the rapidly growing ducts terminal end buds (TEBs) form. The ducts bifurcate until the entire fat pad is filled. The administration of E+P elicits extensive side branching.

\section{Lessons from the genetically engineered mouse models}

The advent of genetically engineered mouse models (GEMMs) provided useful tools for the genetic dissection of biological functions. PR-deficient mice $\left(P R^{-/-}\right)$, both males and females, developed normally but female mutants had multiple reproductive problems, including failure to ovulate. Limited mammary gland development was observed (Lydon et al., 1995). To address to what extent this was due to lack of mammary epithelial PR signaling vs systemic effects caused by the germ line deletion, we adapted the technique of mammary epithelial transplants originally developed to propagate epithelium from mice-bearing hyperplasia (DeOme, 1959). In prepubertal, 3-week-old mice, the rudimentary ductal tree can be surgically removed from the elongated inguinal mammary glands leaving behind a cleared fat pad. A piece of epithelium from a syngeneic mouse grafted to the center of such a cleared fat pad can grow into a new ductal tree that behaves like the endogenous epithelium but does not communicate with the nipple, hence, lactation cannot occur. Engraftment of contralateralcleared fat pads with $W T$ and $P R^{-/-}$epithelium allows one to compare the two within the same normal hormonal milieu and hence to determine the effect of this single gene deletion specifically in the mammary epithelium. $P R^{-/-}$epithelium filled the engrafted fat pad by dichotomous branching albeit with fewer branching points than the WT (Brisken et al., 1998; Rajaram et al., 2015). When the recipients were impregnated, $W T$ grafts, like endogenous control glands, were full of alveoli at the end of pregnancy, whereas the $P R^{-/-}$epithelium showed only dichotomous branching, no side branching nor any alveologenesis. Together with the endocrine ablation and replacement studies discussed above, these genetic tissue recombination experiments show that progesterone, acting through the mammary epithelial PR, drives the cell expansion during pregnancy that results in side branching and subsequent alveologenesis during recurrent estrous cycles and pregnancy.

The $P R$ gene has two promoters resulting in translation from two different AUGs. The shorter PR-A isoform lacks a 165 amino acid stretch at the N-terminus that encodes a PR-B-specific transactivation function (Sartorius et al., 1994) and shows different transcriptional activities (Richer et al., 2002). The two forms were reported to be differentially expressed during development with the A-form decreasing during pregnancy (Aupperlee et al., 2005) and to be regulated in distinct ways by estrogens and progesterone and along the estrous cycle as assessed by IHC (Shyamala et al., 1998). Isoform-specific deletions revealed that PR-A is required for uterine function, but not essential for the response of the mammary gland to progesterone (Mulac-Jericevic et al., 2000). $P R-B^{-/-}$females were fertile; mammary gland development was deficient; more specifically, side branching during pregnancy was reduced albeit not completely as in $P R^{-/-}$females. Moreover, in contrast to $P R^{-/-}$mice, alveologenesis was observed in $P R-B^{-/-}$females (Mulac-Jericevic et al., 2003). As different endocrine perturbances are encountered in the distinct $P R$-mutant strains, which may confound the interpretation of the observed phenotypes, the mice were ovariectomized and subsequently treated with either $\mathrm{E}$ or $\mathrm{E}+\mathrm{P}$. The side branching elicited by $\mathrm{E}+\mathrm{P}$ administration in $P R-A^{-/}$females was comparable to that observed in their $W T$ controls, abrogated in $P R^{-/-}$and reduced in $P R-B^{-/-}$females (Mulac-Jericevic et al., 2003). Hence, PR-B is required for ductal side branching and PR-A is required for alveologenesis. This indicates that PR-A and PR-B have context-dependent roles in the mammary epithelium. Whether these relate to specific transcriptional activation 
of specific target genes and/or different interactions with the ER, which has growth-stimulatory role during puberty and growth-inhibitory role in pregnancy (Cagnet et al., 2018) and or depends on the amount of ligands around remains to be determined.

A differential role for the two forms in human breast cancer is emerging with the PR-A form specifically upregulated in breast cancer as reviewed by Horwitz \& Sartorius (2020) in this issue.

\section{Developmental control of PR expression}

An additional level of complexity of PR signaling in normal physiology stems from the differential developmental regulation of the expression of the receptor itself. PR protein expression by immunohistochemistry is first detected around postnatal day 10 (Rajaram et al., 2015). During puberty, the receptor is expressed in most of the cells constituting the inner layer of the milk ducts, the luminal epithelial cells. In adulthood, its expression becomes more confined and only about $30-50 \%$ of the luminal cells are $\mathrm{PR}+$, this proportion decreases further during pregnancy (Grimm et al., 2002). Analysis of the mammary glands of $P R R^{l a c Z}$ reporter mice at different developmental stages revealed changing regulation of $P R$ promoter with transcription already occurring in the ducts of the embryonic mammary gland (Ismail et al., 2002). During puberty, $L a c Z$ was widely transcribed in the luminal epithelial cells and body cells of the terminal end buds. B-galactosidase activity was not detected in cap cells nor myoepithelial cells, nor in periductal fibroblasts, adipocytes or endothelial cells. In the adult female, $P R$ expression was attenuated and a nonuniform expression pattern was observed with high expression at the tips of the budding side branches and decreased activity by the end of pregnancy (Ismail et al., 2002) indicating that the discrete and changing expression patterns of the PR observed by IHC are determined at the transcriptional level.

\section{Cell intrinsic and paracrine signaling}

The variegated expression of ER and PR in the adult mammary gland is also observed in other animal species and in humans. It was first shown in the human breast that most of the proliferating cells in the normal breast epithelium are ER/PR negative by IHC (Clarke et al., 1997), an observation that confirmed in rats (Russo et al., 1999) and mice (Seagroves et al., 2000). Mixtures of mammary epithelial cells from $P R^{-/-} . R O S A 26+$ females with an excess of WT.ROSA26- mammary epithelial cells were used to reconstitute cleared mammary fat pads. The resulting chimeric glands showed that in the context of surrounding $W T$ cells, $P R^{-/}-. R O S A 26+$ mammary epithelial cells were able to contribute to side branching and alveologenesis during pregnancy (Brisken et al., 1998). This established that progesterone-induced side branching and alveolar budding can be elicited by one or more paracrine signals and led to a model whereby PR+ cells, or a subset thereof, function as hormone sensors that act as organizers and translate the systemic signal into paracrine signals that enable neighboring PR negative cells to proliferate and activate stem and progenitor cells (Brisken and Duss, 2007) (Fig. 3). This organizational structure is a means of coordinating the behavior of multiple cell types, as well as a way of propagating locally a fluctuating systemic signal over time.

Subsequently, a number of factors were identified as downstream mediators of PR signaling either by candidate approaches or through global gene expression profiling (Fernandez-Valdivia et al., 2008; Lain et al., 2013, 2015). Among the PR targets in the adult mouse mammary gland are a number of genes encoding secreted factors including receptor activator of NFkB (Rankl) (Brisken et al., 2002; Cao et al., 2001; Mulac-Jericevic et al., 2003), Wnt4 (Brisken et al., 2000), Calcitonin (Ismail et al., 2004), CXCL-12 (Shiah et al., 2015), Amphiregulin (Aupperlee et al., 2013), and Adamts18 (Ataca et al., 2020). Here on, we will describe what has been revealed about the importance in mediating distinct biological aspects of PR signaling function in vivo. Of note, the rat model was used to identify PR targets by ChIP-seq and revealed that networks relating to cell cycle and FGF and ErbB signaling were enriched (Ding et al., 2019).

\section{Cell proliferation: intrinsic and paracrine effects of PR signaling}

Cell proliferation is the aspect that is easiest to dissect because it can readily be assessed by BrdU incorporation. Upon ovariectomy, cell proliferation in the mammary epithelium ceases and ducts become atrophic. Administration of estrogen to adult ovariectomized mice elicits little proliferation (Wang et al., 1990), but induces the expression of the PR. Co-administration of $\mathrm{E}$ and $\mathrm{P}$ causes extensive cell proliferation in the epithelium (Wang et al., 1990). This occurs in two waves; the first small wave, revealed by BrdU incorporation occurs in $\mathrm{PR}+$ cells within $24 \mathrm{~h}$ of stimulation, and it is followed by a much larger wave of cell proliferation entailing 


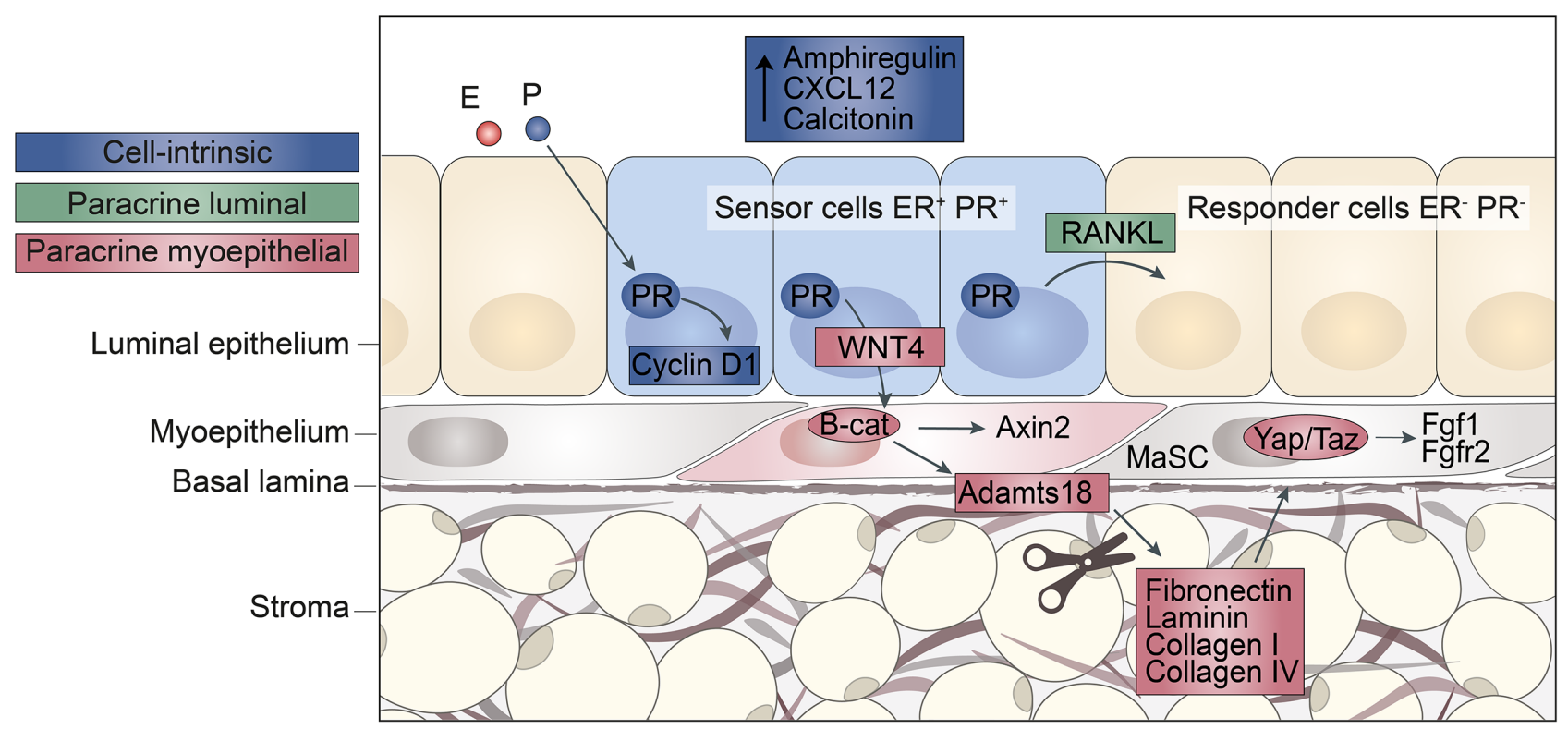

\section{Figure 3}

The progesterone signaling hub in the adult mammary epithelium progesterone, upon binding to its receptor in the ER+/PR+ sensor cells (blue) activates different signaling pathways. It can stimulate cell-intrinsic proliferation by a cyclin D1-dependent mechanism (blue) and induce secreted factors like Amphiregulin, CXCL12, or Calcitonin (blue). Distinct PR+ cells induce Wnt4, which acts on the myoepithelium where it activated canonical Wnt signaling, which results in the expression of the secreted protease Adamts 18 that cleaves fibronectin. As a result the ECM, part of the stem cells niche, is biochemically altered with resulting activation of the hippo signalling pathway and increased transcription of FGFR signaling components (red). In other $\mathrm{PR}+$ cells, Rankl is induced that induces the proliferation of neighboring ER-/PR- responder cells (green).

PR-negative cells. The first type of proliferation of ER/PR+ cells is cyclin D1 dependent; it fails to occur in cyclin $\mathrm{D} 1^{-/-}$ epithelium, the second, larger wave of cell proliferation, occurring in cells which are PR negative, is Rankl dependent (Beleut et al., 2010). The importance of Rankl in mediating the proliferative response to $\mathrm{P}$ was illustrated by MMTV-Rankl transgenics which show side branching and alveolar budding in the absence of progesterone stimulation (Fernandez-Valdivia et al., 2009) and a very elegant GEMM, in which Rankl was specifically induced in the ER+ sensor cells of $P R^{-/-}$mice and shown to rescue side branching and alveologenesis (Mukherjee et al., 2010).

\section{Stem cell activation}

The realization that the most frequent insertion site of the MMTV virus in the mammary epithelium, the int1 locus (Nusse \& Varmus, 1982), harbored a gene with sequence homology to the drosophila wingless gene (Wnt1) lead early on to interest in Wnt signaling in mammary gland development and in the context of breast cancer. Overexpression of Wnt 1 in the mammary gland under the control of the MMTV LTR, drastically altered the mouse mammary gland resulting in a brush-like appearance of the milk ducts with excessive side branches and caused mammary tumors (Tsukamoto et al., 1988).
Various Wnt transcripts were detected and shown to have developmentally regulated expression pattern (Dale et al., 1996; Gavin \& McMahon, 1992). Of these, specifically Wnt4 was induced by progesterone and to a lesser extent by estrogen in the mammary glands of ovariectomized adult mice (Brisken et al., 2000) and its overexpression in mammary epithelial cells mimicked the effects of Wnt1 and elicited pregnancy-like changes (Bradbury et al., 1995). Ectopic expression of Wnt1 by means of a MMTV:Wnt1 transgene (Tsukamoto et al., 1988) overcame the side branching defect of $\mathrm{PR}^{-/-}$epithelia showing that Wnt signaling is important downstream of $P R$. Moreover, ectopic Wnt-1 expression induced side branching of $P R^{-/}$epithelia by a paracrine mechanism as shown by generating chimeric epithelia of $P R^{-/-}$and $M M T V-W n t 1+$ mammary epithelial cells (Brisken et al., 2000).

Evidence emerged that Wnt signaling pathway is important for adult stem cells in many organs (Reya \& Clevers, 2005). The ability of individual mammary epithelial cells to give rise to mammospheres (Dontu et al., 2003) became a useful assay for stem cells and was shown to correlate with the ability to reconstitute mammary fat pads (Cicalese et al., 2009; Pece et al., 2010). Furthermore, stem cells were defined by FACS profiling based on the expression of ITGB1 or ITGA6 and functionally validated by limiting dilution assays (Shackleton et al., 2006; 
Stingl et al., 2006), which turned into the golden assay of mammary stem cells. By these assays Rankl, Wnt4 and Cxcl12/CxcR4 were shown to be important downstream of $\mathrm{P}$ in activating stem cells (Asselin-Labat et al., 2010; Joshi et al., 2010; Shiah et al., 2015).

However, it is important to consider that the expression of various integrins used as stem cell markers itself can be subject to hormonal regulation, and their expression at the cell surface may be affected by changes in the ECM secondary to hormonal stimulation. Hence, an increase in cell populations expressing these markers does not necessarily reflect an increase in the number of stem cells, but may reflect an increased expression of the specific antigens on the cell surface. In addition, a more complex issue lies in the cleared fat pad assay itself. Before any cell that is injected into the fat pad can unfold its stem cell potential, it needs to adjust to the non-physiological environment, to survive and interact with the cells and matrix of the mammary stroma. It is conceivable that a mutation impairs these abilities of an otherwise perfect mammary stem cell. As a result, even the ideal mammary stem cell will not survive and/or not give rise to an outgrowth and therefore not be scored as a stem cell. Of note, both, cell survival and interactions with ECM and stromal cells, are dependent on integrin signaling and it is conceivable that the presence of these stem cell markers bestows an adhesion and survival advantage. In contrast, the luminal cells, at least some of which show plasticity and high proliferative capacity in vivo may simply not get to unfold their stem cell properties in this assay because they lack the integrins required for survival and interaction with the mammary matrix. In line with this, lineage tracing experiments have revealed plasticity of luminal cells (Van Keymeulen et al., 2011, 2017) and vice versa identified rare luminal cells that can give rise to ER+ basal cells during pregnancy (Song et al., 2019).

A more comprehensive assay for the regenerative potential of the mammary epithelium is the serial transplantation assay, in which a piece of mammary epithelium is transplanted for seven subsequent generations (Daniel, 1973). Comparison of different mutants by this assay revealed that Wnt4 deletion had the most severe effect on the regenerative potential of the mammary epithelium followed by $P R$, whereas Rankl deletion did not significantly affect the serial reconstitution ability (Rajaram et al., 2015). These findings indicate that PR signaling is required for the induction of stem cell potential and requires Wnt 4 for this function. A likely explanation for the finding that Wnt4 deletion causes a more severe defect than $P R$ abrogation is that ER signaling is involved in the control of Wnt4 expression during earlier developmental stages (Rajaram et al., 2015).

\section{ECM/basal membrane restructuring}

The PR target, Wnt4, activates canonical Wnt signaling in the myoepithelium as shown genetically with the use of a reporter of the canonical Wnt signaling target, Axin2 (Lustig et al., 2002; Rajaram et al., 2015). Consistently, global gene expression changes resulting from conditional deletion of the direct PR target Wht4 in the mammary epithelium are more striking in the myoepithelial than in the luminal cell compartment (Ataca et al., 2020). Among the indirect progesterone targets in the myoepithelium is Adamts18, a secreted protease, which provides a molecular link between the luminal PR signaling and changes in the ECM.

Deletion of Adamts18 in the mammary epithelium results in delayed ductal outgrowth and side branching but normal alveologenesis, reminiscent of, but less severe than the phenotype of Wnt4-/ mammary epithelium. Adamts18-/- mammary epithelium has decreased serial transplantation capacity indicating that the protease affects stem cells. Analysis of ADAMTS18 interactors in the MCF10A cell line model by mass spectometry revealed that the protease interacts with multiple basal membrane proteins. In line with its role being pertinent to the basal membrane and the basal membrane being part of the stem cell niche Adamts18 interacts genetically with the basal membrane-specific Collagen18A1 in mammary gland development and in controlling the regenerative potential of the mammary epithelium (Ataca et al., 2020).

Of note, major effects on accumulation of ECM proteins, like fibronectin, laminin, collagen I and IV were observed specifically during puberty but not in the adult mammary gland suggesting that the role of PR in controlling stem cells is particularly important in puberty. However, additional, yet to be discerned changes in the ECM may be elicited by Adamts18 at later stages. In any case, the ability of progesterone to induce a secreted protease that can cleave fibronectin (Ataca et al., 2020), which is central to ECM assembly, provides a mechanistic link between epithelial hormone signaling and stromal changes.

\section{Stage-specific roles of PR signaling}

Taken together, a picture emerges, in which PR signaling has at least three distinct roles in the normal mammary 
epithelium (Fig. 4). The first is during puberty, when progesterone levels are low and PR expression is high and widespread in the mammary epithelium. At this stage, the hormone, contributes to the induction of Wnt4 and Adamts18 expression which are involved in controlling mammary stem cells and their niches. This axis is maintained during adulthood when signaling is recurrently activated during diestrus but possibly most important during puberty.

The second function is important in adulthood, with recurrent estrus cycles and during pregnancy, where PR signaling stimulates some cell-intrinsic proliferation via cyclin D1 and elicits the extensive cell proliferation that is required to establish side branches by inducing Rankl expression. At this stage, all Rankl expressing cells are PR+, however, not all the PR+ cells express detectable levels of Rankl (Beleut et al., 2010), similarly, all Wnt4 expressing cells are $\mathrm{PR}+$, yet, not all the $\mathrm{PR}+$ cells express Wnt4 (Rajaram et al., 2015). This points to the possibility that different subsets of PR+ cells have different assignments in the progesterone orchestra and begs the questions whether the different transcriptional outcomes reflect stochastic events or depend on different cellular contexts laid down by distinct epigenetic profiles.

The third role of the PR is during the last third stage of pregnancy and relates to alveologenesis and requires PR-A. In $P R-B^{-/-}$females, Rankl and Wnt4 induction by $\mathrm{E}+\mathrm{P}$ in ovariectomized adult females is abrogated, yet, alveologenesis occurs in $P R-B^{-/-}$females, but not in $P R^{-/}$females (Mulac-Jericevic et al., 2000, 2003). This indicates that the presence of PR-A isoform is sufficient for alveologenesis to occur and that alveologenesis occurs independent of the paracrine mediators Rankl and Wnt4. It is tempting to speculate that this may relate to PR-A isoform specific interactions with the ER, which has an important but barely understood inhibitory role in this process (Cagnet et al., 2018).

\section{Implications for breast cancer}

It is intuitive that induction of progesterone-dependent activities such as stem/progenitor cell activation, cell proliferation, and ECM modifications, if they occur similarly in the human breast in the context of recurrent luteal phases and/or progestin containing treatments, may promote carcinogenesis in the breast. This could, at least partly, explain why menstrual cycles and hormonal contraception, as well as combined HRT, all of which result in PR signaling, increase BC risk. But are the same signals operating in the human breast?

Studies with reduction mammoplasty-derived normal breast epithelial cells cultured in Matrigel revealed that progesterone stimulates cell proliferation and increases the number of progenitor cells (Graham et al., 2009). However, neither RANKL nor WNT4 expression were induced in this model. To address whether the same

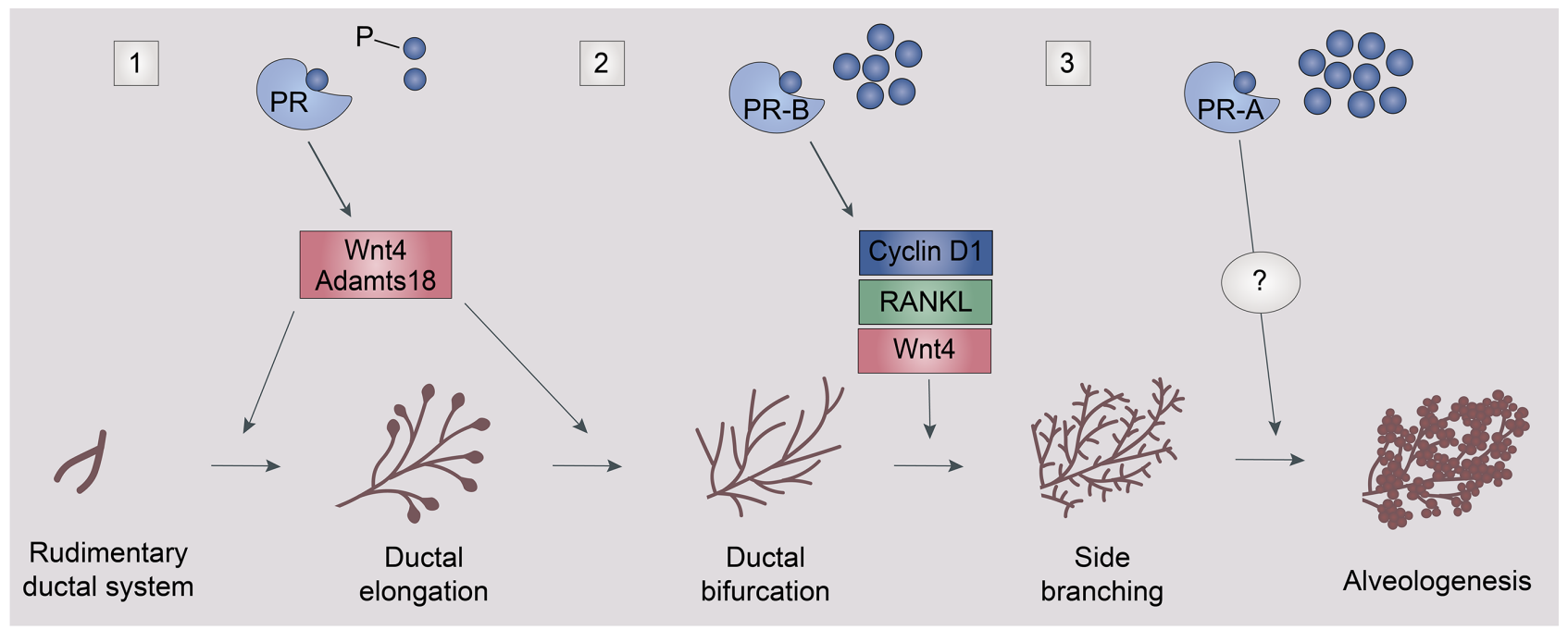

Figure 4

Stage-specific outcome of PR signaling scheme of mammary gland development highlighting different functions of PR at different developmental stages. During puberty (1) PR signaling drives directly Wnt4 and indirectly Adamts18 expression both of which are important for the activation of mammary stem cells. In the adult mammary gland, during diestrous and during pregnancy (2), PR-B signaling relies on cyclinD1, Rankl and Wnt4 to drive the extension cell proliferation that results in side branching. During the last third stage of pregnancy (3) there is a role for PR-A in alveologenesis revealed through genetic experiments. The underlying mechanisms are still poorly understood. 
pathways are pertinent in the human breast epithelium, we developed an ex vivo approach to test hormone response. Fresh reduction mammoplasty specimens were mechanically disrupted and enzymatically digested to isolate tissue microstructures that consist of epithelia and associated stromal cells (Sflomos et al., 2015; Tanos et al., 2013). Keeping the intercellular connections intact preserved the hormone response for at least $72 \mathrm{~h}$. In this ex vivo model, progesterone induced both RANKL and WNT4 transcripts. Moreover, functionally, progesterone-induced cell proliferation was inhibited in the presence of the recombinant decoy receptor osteoprotegerin (rOPG) (Tanos et al., 2013), a finding confirmed in ex vivo experiments with tissue from BRCA1 mutation carriers (Nolan et al., 2016). As observed in the mouse mammary gland, RANKL protein localized exclusively to PR+ cells, but not all PR+ cells showed detectable RANKL expression (Tanos et al., 2013). Importantly, the physiological relevance of the finding in the ex vivo model was shown through analysis of normal breast biopsies. The RANKL protein was not detected by IHC in the breast epithelium from women in follicular phase, but in samples from women with the high serum progesterone levels characteristic of luteal phase. Furthermore, its expression was higher and more widespread in samples from pregnant women who have yet higher progesterone levels (Tanos et al., 2013).

A study on tumor and contralateral normal breast tissue samples from premenopausal breast cancer patients with menstrual cycle staging through hormone measurements, confirmed the increase in RANKL expression related to high progesterone levels in the normal breast (Hu et al., 2014). Furthermore, together with other studies it revealed that RANKL transcripts are also regulated in ER/PR+ tumors (Haynes et al., 2013, 2014). Interestingly, in the normal breast epithelium increased mitotic activity has been reported to occur during luteal phase when progesterone levels are high (Anderson et al., 1982; Ferguson \& Anderson, 1981; Pardo et al., 2014), but ER+ tumors proliferation-associated genes were decreased when progesterone levels peaked (Haynes et al., 2014, 2019). It needs to be evaluated whether this discrepancy may be related to different experimental approaches or whether this is an indication that PR signaling and cell cycle control are wired differently in normal breast epithelial cells and cancer cells.

Most insights into physiologic gene expression changes in the human breast epithelium comes from the work of Susan Clare and her colleagues, who drove the efforts leading to the Susan Komen tissue bank, which is a collection of normal breast tissue from healthy volunteers of different ages and races (Sherman et al., 2012). Hormone levels at the time of tissue sampling can be determined and samples thereby be attributed to follicular vs luteal phases of the menstrual cycle. When 20 samples from healthy breast tissue donors were used to isolate mammary epithelium by laser capture microdissection and RNA sequencing was performed, 255 genes were found to be differentially expressed in luteal phase vs follicular with 221 increased in the luteal phase (Pardo et al., 2014). Most of them related to DNA replication, DNA damage, and mitosis. Both RANKL and WNT4 were found to be increased in luteal phase together with a third paracrine factor EPIREG, known to bind ErbB1 and ErbB4, reviewed in (Riese \& Cullum, 2014).

Furthermore, the secreted proteases, MMP3 and ADAMTS9 were significantly increased. RNA from myoepithelial cells represent a smaller fraction than luminal cell RNA and this may have precluded that ADAMTS18 reached significance in this relatively small data set. The protease was induced by progesterone in xenografted human breast epithelial cells (Ataca et al., 2020). These findings may have important clinical implications; mammographic density is the single most important risk factor for breast cancer (Boyd et al., 2007; McCormack \& dos Santos Silva, 2006) and has been correlated with progestin intake levels (Greendale et al., 2003; Vachon et al., 2002). While the role of the individual proteases remains to be dissected, they may provide insights into the molecular mechanisms underlying increased breast density and offer new targets for preventive strategies.

Together, these findings suggest that the organizational principles and major signaling axes are conserved between mice and humans and that hence recurrent activation of PR signaling may promote breast carcinogenesis.

An additional pathway that emerged from studies with human cells and tissue sections is the GHR signaling. $\mathrm{GH}$ is induced by progesterone in the breast epithelium in cells in direct vicinity of PR+ cells and was shown to act on ER-/PR- progenitor cells, which express the GHR (Lombardi et al., 2014). Interestingly, the GH receptor transcript was also increased during the luteal phase (Pardo et al., 2014). An interesting scenario was proposed that pituitary GH may stimulate mammary stem cells during pubertal growth, whereas in the adult organism when systemic GH release largely subsided, GH can be produced locally under the control of PR signaling for progenitor cell expansion (Lombardi et al., 2014).

Another question of outstanding clinical importance is the role of PR signaling alterations in the context of 
endocrine resistance and metastasis. Decreased or lost expression of PR, independent of ER signaling activity (Kim et al., 2006; Piva et al., 2014), and PR mutations have been reported in ER+ metastatic breast cancer (Fowler et al., 2020).

\section{Open questions, challenges and outlook}

Given its preeminent role in tumor-promoting activities, PR signaling is clearly an attractive target for cancer preventive strategies. To what extent the mechanisms we discussed are operational in tumor cells and whether it may also be useful to target the receptor in cancer is debated while estrogen is widely accepted as a driving force of breast cancer. Evidence that progesterone may stimulate cancer stem cells has accumulated, reviewed in (Axlund \& Sartorius, 2012), however, RANKL and WNT4 are not induced by progesterone in most $\mathrm{ER}+/ \mathrm{PR}+$ breast cancer cell lines and in various xenograft models progesterone antagonizes E2-induced growth (Mohammed et al., 2015; Singhal et al., 2016). It is important to better understand how the two players, ER and PR interact with each other when they synergize in the normal breast epithelium and if and/or how their interactions change during carcinogenesis. How does the change in ratio of the Aand B- isoforms affect PR signaling and its interactions with ER? Relative expression of the PR-A isoform is increased in tumor cells, how this affects PR signaling and/or interactions with other family members like the androgen and the glucocorticoid receptor?

The dissociation between HR expression and cell proliferation described in the normal breast is not observed in tumors where most of the proliferating cells are ER+ and by extension PR+ (Clarke et al., 1997). Indeed, abrogation of the dissociation between hormone receptor expression and cell proliferation is part of the earliest alterations that characterizes precursor lesions that show uniform ER/PR expression. The variegated expression characteristic of the adult breast epithelium is lost and all luminal cells express ER (Lee et al., 2007). How is this alteration brought about and how does it affect PR signaling? Throughout this review we distinguished PR+ and PR- luminal cells. This widely used dichotomy, however, is based on the somewhat arbitrary interpretation of IHC. Tissue recombination studies with mammary epithelial cells from different Esr1 mutant GEMMs revealed that the ER is functionally important in cells that are ER negative by IHC. Indeed, about $50 \%$ of these ER-IHC-negative cells were found to express detectable levels of Esr1 transcript suggesting that there are at least three distinct luminal cell population with regards to ER status: $\mathrm{IHC}+\mathrm{RNA}+$, IHC- RNA+, and IHC-/RNA; alternatively, there may be a gradient of ER positivity (Cagnet et al., 2018). The same scenario may apply to PR expression as well and may complicate the interpretation of PR signaling activities in the mammary gland when these are assessed across the epithelium. It prompts the question of whether PR expression levels are a stable feature of distinct cell populations or merely a transient characteristic that can fluctuate over time, that is, low level expression may reflect recent signaling activities, as PR transcription is under negative control by PR signaling (Alexander et al., 1989). Expression of the PR in a subset of myoepithelial/progenitor cells has been reported (Hilton et al., 2014). Ever more powerful single cell analyses approaches are likely to provide the key to understand the intercellular heterogeneity of PR signaling.

The ex vivo models increasingly used to study hormone signaling (Sflomos et al., 2015) have severe limitations when it comes to biochemical analyses, they are highly variable and because of the complex and changing cell composition difficult to interpret. However, combined with single cell analyses new opportunities arise and new culture approaches may extend their lifetime (C. Brito, personal communication). Furthermore, the possibility to xenograft hormone-sensitive tumor cells and normal human breast epithelial cells (Sflomos et al., 2016) to the milk ducts of immunocompromised mice and to study them there opens new experimental opportunities that will allow to address some of these questions in the near future.

\section{Declaration of interest}

The authors declare that there is no conflict of interest that could be perceived as prejudicing the impartiality of the research reported.

\section{Funding}

This work was supported by the Swiss Cancer League (KFS-3701-08-2015 Lobular carcinoma of the breast: insights from a new PDX models) and the Biltema and ISREC Foundation.

\section{Acknowledgments}

The authors thank G. Ambrosini for critical reading of the manuscript.

\section{References}

Abbassi-Ghanavati M, Greer LG \& Cunningham FG 2009 Pregnancy and laboratory studies: a reference table for clinicians. Obstetrics \& 
Gynecology 114 1326-1331. (https://doi.org/10.1097/

AOG.0b013e3181c2bde8)

Aggeler J, Ward J, Blackie L, Barcellos-Hoff M, Streuli C \& Bissell M 1991 Cytodifferentiation of mouse mammary epithelial cells cultured on a reconstituted basement membrane reveals striking similarities to development in vivo. Journal of Cell Science 99 p407-p417.

Alexander IE, Clarke CL, Shine J \& Sutherland RL 1989 Progestin inhibition of progesterone receptor gene expression in human breast cancer cells. Molecular Endocrinology 3 1377-1386. (https://doi. org/10.1210/mend-3-9-1377)

Anderson TJ, Ferguson DJ \& Raab GM 1982 Cell turnover in the 'resting' human breast: influence of parity, contraceptive pill, age and laterality. British Journal of Cancer 46 376-382. (https://doi. org/10.1038/bjc.1982.213)

Asselin-Labat ML, Vaillant F, Sheridan JM, Pal B, Wu D, Simpson ER, Yasuda H, Smyth GK, Martin TJ, Lindeman GJ, et al. 2010 Control of mammary stem cell function by steroid hormone signalling. Nature 465 798-802. (https://doi.org/10.1038/nature09027)

Ataca D, Aouad P, Constantin C, Laszlo C, Beleut M, Shamseddin M, Rajaram RD, Jeitziner R, Mead TJ, Caikovski M, et al. 2020 The secreted protease Adamts18 links hormone action to activation of the mammary stem cell niche. Nature Communications 111571. (https://doi.org/10.1038/s41467-020-15357-y)

Aupperlee MD, Smith KT, Kariagina A, Haslam SZ. 2005. Progesterone receptor isoforms $\mathrm{A}$ and $\mathrm{B}$ : temporal and spatial differences in expression during murine mammary gland development. Endocrinology 146 3577-3588. (https://doi.org/10.1210/en.2005-0346)

Aupperlee MD, Leipprandt, JR, Bennett, JM, Schwartz, RC, Haslam, SZ. 2013. Amphiregulin mediates progesterone-induced mammary ductal development during puberty. Breast Cancer Research 15 R44. (https://doi.org/10.1186/bcr3431)

Axlund SD, Sartorius CA. 2012. Progesterone regulation of stem and progenitor cells in normal and malignant breast. Molecular and Cellular Endocrinology 357 71-79. (https://doi.org/10.1016/j. mce.2011.09.021)

Beleut M, Rajaram RD, Caikovski M, Ayyanan A, Germano D, Choi Y, Schneider P \& Brisken C. 2010. Two distinct mechanisms underlie progesterone-induced proliferation in the mammary gland. PNAS 107 2989-2994. (https://doi.org/10.1073/pnas.0915148107)

Boyd NF, Guo H, Martin LJ, Sun L, Stone J, Fishell E, Jong RA, Hislop G, Chiarelli A, Minkin S, et al. 2007. Mammographic density and the risk and detection of breast cancer. New England Journal of Medicine 356 227-236. (https://doi.org/10.1056/NEJMoa062790)

Bradbury JM, Edwards PA, Niemeyer CC, \& Dale TC 1995. Wnt-4 expression induces a pregnancy-like growth pattern in reconstituted mammary glands in virgin mice. Developmental Biology 170 553-563. (https://doi.org/10.1006/dbio.1995.1236)

Brisken C 2013. Progesterone signalling in breast cancer: a neglected hormone coming into the limelight. Nature Reviews Cancer 13 385-396. (https://doi.org/10.1038/nrc3518)

Brisken C \& Duss S 2007. Stem cells and the stem cell niche in the breast: an integrated hormonal and developmental perspective. Stem Cell Reviews 3 147-156. (https://doi.org/10.1007/s12015-007-0019-1)

Brisken C, Park S, Vass T, Lydon JP, O’Malley BW \& Weinberg, RA. 1998. A paracrine role for the epithelial progesterone receptor in mammary gland development. PNAS 95 5076-5081. (https://doi.org/10.1073/ pnas.95.9.5076)

Brisken C, Heineman A, Chavarria T, Elenbaas B, Tan J, Dey S, McMahon J, McMahon A, \& Weinberg R. 2000. Essential function of Wnt-4 in mammary gland development downstream of progesterone signaling. Genes \& Development 14 p650-4.

Brisken C, Ayyannan A, Nguyen C, Heineman A, Reinhardt F, Tan J, Dey SK, Dotto GP, \& Weinberg RA 2002. IGF-2 is a mediator of prolactin-induced morphogenesis in the breast. Developmental Cell $\mathbf{3}$ 877-887. (https://doi.org/10.1016/s1534-5807(02)00365-9)
Cagnet S, Ataca D, Sflomos G, Aouad P, Schuepbach-Mallepell S, Hugues H, Krust A, Ayyanan A, Scabia V \& Brisken C 2018. Oestrogen receptor $\alpha$ AF-1 and AF-2 domains have cell population-specific functions in the mammary epithelium. Nature Communications 9 4723. (https://doi.org/10.1038/s41467-018-07175-0)

Cao Y, Bonizzi G, Seagroves TN, Greten FR, Johnson R, Schmidt EV \& Karin M 2001. IKKalpha provides an essential link between RANK signaling and cyclin D1 expression during mammary gland development. Cell 107 763-775. (https://doi.org/10.1016/s00928674(01)00599-2)

Cicalese A, Bonizzi G, Pasi CE, Faretta M, Ronzoni S, Giulini B, Brisken C, Minucci S, Di Fiore, PP, \& Pelicci PG 2009. The tumor suppressor p53 regulates polarity of self-renewing divisions in mammary stem cells. Cell 138 1083-1095. (https://doi.org/10.1016/j. cell.2009.06.048)

Clarke RB, Howell A, Potten CS \& Anderson E 1997. Dissociation between steroid receptor expression and cell proliferation in the human breast. Cancer Research 57 4987-4991.

Colditz, GA, Rosner BA, Chen WY, Holmes MD, \& Hankinson SE 2004. Risk factors for breast cancer according to estrogen and progesterone receptor status. Journal of the National Cancer Institute 96 218-228. (https://doi.org/10.1093/jnci/djh025)

Dale TC, Weber-Hall SJ, Smith K, Huguet EL, Jayatilake H, Gusterson BA, Shuttleworth G, O'Hare M \& Harris AL 1996. Compartment switching of WNT-2 expression in human breast tumors. Cancer Research 56 4320-4323.

Daniel CW 1973. Finite growth span of mouse mammary gland serially propagated in vivo. Experientia 29 1422-1424.

DeOme KB 1959. Development of mammary tumors from hyperplastic alveolar nodiles transplanted into gland-free mammary fat pads of female C3H mice. Cancer Research 19 511-520.

Ding L, Shunkwiler LB, Harper NW, Zhao Y, Hinohara K, Huh SJ, Ekram MB, Guz J, Kern MJ, Awgulewitsch A, et al 2019. Deletion of Cdkn1b in ACI rats leads to increased proliferation and pregnancyassociated changes in the mammary gland due to perturbed systemic endocrine environment. PLoS Genetics 15 e1008002. (https://doi. org/10.1371/journal.pgen.1008002)

Dontu G, Abdallah WM, Foley JM, Jackson KW, Clarke MF, Kawamura MJ \& Wicha MS 2003. In vitro propagation and transcriptional profiling of human mammary stem/progenitor cells. Genes \& Development 17 1253-1270. (https://doi.org/10.1101/ $\operatorname{gad} .1061803)$

Dwyer AR, Truong TH, Ostrander JH \& Lange CA 2020. Steroid receptors as MAPK signaling sensors in breast cancer: let the fates decide. Journal of Molecular Endocrinology 65 T35-T48. (https://doi. org/10.1530/JME-20-0274)

Elmlinger MW, Kühnel W \& Ranke MB 2002. Reference ranges for serum concentrations of lutropin (LH), follitropin (FSH), estradiol (E2), prolactin, progesterone, sex hormone-binding globulin (SHBG), dehydroepiandrosterone sulfate (DHEAS), cortisol and ferritin in neonates, children and young adults. Clinical Chemistry and Laboratory Medicine 40 1151-1160. (https://doi.org/10.1515/CCLM.2002.202)

Ferguson DJ \& Anderson TJ 1981. Morphological evaluation of cell turnover in relation to the menstrual cycle in the 'resting' human breast. British Journal of Cancer 44 177-181. (https://doi.org/10.1038/ bjc.1981.168)

Fernandez-Valdivia R, Mukherjee A, Creighton CJ, Buser AC, DeMayo FJ, Edwards DP \& Lydon JP 2008. Transcriptional response of the murine mammary gland to acute progesterone exposure. Endocrinology 149 6236-6250. (https://doi.org/10.1210/en.2008-0768)

Fernandez-Valdivia R, Mukherjee A, Ying Y Li J, Paquet M, DeMayo FJ \& Lydon JP 2009. The RANKL signaling axis is sufficient to elicit ductal side-branching and alveologenesis in the mammary gland of the virgin mouse. Developmental Biology 328 127-139. (https://doi. org/10.1016/j.ydbio.2009.01.019) 
Fowler AM, Salem K, DeGrave M, Ong IM, Rassman S, Powers GL, Kumar M, Michel CJ \& Mahajan AM 2020. Progesterone receptor gene variants in metastatic estrogen receptor positive breast cancer. Hormones and Cancer 11 63-75. (https://doi.org/10.1007/s12672-02000377-3)

Gavin BJ \& McMahon AP 1992. Differential regulation of the Wnt gene family during pregnancy and lactation suggests a role in postnatal development of the mammary gland. Molecular and Cellular Biology 12 2418-2423.

Graham JD, Mote PA, Salagame U, van Dijk JH, Balleine RL, Huschtscha LI, Reddel RR \& Clarke CL 2009. DNA replication licensing and progenitor numbers are increased by progesterone in normal human breast. Endocrinology 150 3318-3326. (https://doi. org/10.1210/en.2008-1630)

Greendale GA, Reboussin BA, Slone S, Wasilauskas C, Pike MC \& Ursin G 2003. Postmenopausal hormone therapy and change in mammographic density. Journal of the National Cancer Institute $\mathbf{9 5}$ 30-37. (https://doi.org/10.1093/jnci/95.1.30)

Grimm SL, Seagroves TN, Kabotyanski EB, Hovey RC, Vonderhaar BK, Lydon JP, Miyoshi K, Hennighausen L, Ormandy CJ, Lee AV, et al 2002. Disruption of steroid and prolactin receptor patterning in the mammary gland correlates with a block in lobuloalveolar development. Molecular Endocrinology 16 2675-2691. (https://doi. org/10.1210/me.2002-0239)

Hagan CR \& Lange CA 2014. Molecular determinants of contextdependent progesterone receptor action in breast cancer. $B M C$ Medicine 12 32. (https://doi.org/10.1186/1741-7015-12-32)

Haslam S \& Shyamala G 1979. Effect of oestradiol on progesterone receptors in normal mammary glands and its relationship with lactation. Biochemical Journal 182 127-131. (https://doi.org/10.1042/ bj1820127)

Haynes BP, Viale G, Galimberti V, Rotmensz N, Gibelli B, A'Hern R, Smith IE \& Dowsett M 2013. Expression of key oestrogen-regulated genes differs substantially across the menstrual cycle in oestrogen receptor-positive primary breast cancer. Breast Cancer Research and Treatment 138 157-165. (https://doi.org/10.1007/s10549-013-2426-0)

Haynes BP, Viale G, Galimberti V, Rotmensz N, Gibelli B, Smith IE \& Dowsett M 2014. Differences in expression of proliferation-associated genes and RANKL across the menstrual cycle in estrogen receptorpositive primary breast cancer. Breast Cancer Research and Treatment 148 327-335. (https://doi.org/10.1007/s10549-014-3181-6)

Haynes BP, Ginsburg O, Gao Q, Folkerd E, Afentakis M, Buus R, Quang LH, Thi Han P, Khoa PH, Dinh NV, et al 2019. Menstrual cycle associated changes in hormone-related gene expression in oestrogen receptor positive breast cancer. NPJ Breast Cancer 542. (https://doi.org/10.1038/s41523-019-0138-2)

Hilton HN, Santucci N, Silvestri A, Kantimm S, Huschtscha LI, Graham JD \& Clarke CL 2014. Progesterone stimulates progenitor cells in normal human breast and breast cancer cells. Breast Cancer Research and Treatment 143 423-433. (https://doi.org/10.1007/ s10549-013-2817-2)

Horwitz KB \& Sartorius CA 202090 years of progesterone: Progesterone and progesterone receptors in breast cancer: past, present, future. Journal of Molecular Endocrinology 65 T49-T63. (https://doi. org/10.1530/JME-20-01014)

Hu H, Wang J, Gupta A, Shidfar A, Branstetter D, Lee O, Ivancic D, Sullivan M, Chatterton RT, Jr. Dougall WC, et al 2014. RANKL expression in normal and malignant breast tissue responds to progesterone and is up-regulated during the luteal phase. Breast Cancer Research and Treatment 146 515-523. (https://doi.org/10.1007/ s10549-014-3049-9)

Ismail PM, Li J, DeMayo FJ, O’Malley BW \& Lydon JP 2002. A novel LacZ reporter mouse reveals complex regulation of the progesterone receptor promoter during mammary gland development. Molecular Endocrinology 16 2475-2489. (https://doi.org/10.1210/me.200201690)
Ismail PM, DeMayo FJ, Amato P \& Lydon JP 2004. Progesterone induction of calcitonin expression in the murine mammary gland. Journal of Endocrinology 180 287-295. (https://doi.org/10.1677/ joe.0.1800287)

Joshi PA, Jackson HW, Beristain AG, Di Grappa MA, Mote PA, Clarke CL, Stingl J, Waterhouse PD \& Khokha R 2010. Progesterone induces adult mammary stem cell expansion. Nature 465 803-807. (https:// doi.org/10.1038/nature09091)

Kastner P, Krust A, Turcotte B, Stropp U, Tora L, Gronemeyer H \& Chambon P 1990. Two distinct estrogen-regulated promoters generate transcripts encoding the two functionally different human progesterone receptor forms A and B. EMBO Journal 9 1603-1614. (https://doi.org/10.1002/j.1460-2075.1990.tb08280.x)

Keydar I, Chen L, Karby S, Weiss FR, Delarea J, Radu M, Chaitcik S \& Brenner HJ 1979. Establishment and characterization of a cell line of human breast carcinoma origin. European Journal of Cancer 15 659-670. (https://doi.org/10.1016/0014-2964(79)90139-7)

Kim H-J, Cui X, Hilsenbeck SG \& Lee AV 2006. Progesterone receptor loss correlates with human epidermal growth factor receptor 2 overexpression in estrogen receptor-positive breast cancer. Clinical Cancer Research 12 1013s-1018s. (https://doi.org/10.1158/1078-0432. CCR-05-2128)

Kratz A, Ferraro M, Sluss PM \& Lewandrowski KB 2004. Case records of the Massachusetts General Hospital. Weekly clinicopathological exercises. Laboratory reference values. The New England Journal of Medicine 351 1548-1563. (https://doi.org/10.1056/NEJMcpc049016)

Lain AR, Creighton CJ \& Conneely OM 2013. Research resource: progesterone receptor targetome underlying mammary gland branching morphogenesis. Molecular Endocrinology 27 1743-1761. (https://doi.org/10.1210/me.2013-1144)

Lee S, Medina D, Tsimelzon A, Mohsin SK, Mao S, Wu Y \& Allred DC 2007. Alterations of gene expression in the development of early hyperplastic precursors of breast cancer. American Journal of Pathology 171 252-262. (https://doi.org/10.2353/ajpath.2007.061010)

Liu Z, Speroni L, Quinn KP, Alonzo C, Pouli D, Zhang Y, Stuntz E, Sonnenschein C, Soto AM \& Georgakoudi I 2018. 3D organizational mapping of collagen fibers elucidates matrix remodeling in a hormone-sensitive 3D breast tissue model. Biomaterials 179 96-108. (https://doi.org/10.1016/j.biomaterials.2018.06.036)

Lombardi S, Honeth G, Ginestier C, Shinomiya I, Marlow R, Buchupalli B, Gazinska P, Brown J, Catchpole S, Liu S, et al. 2014. Growth hormone is secreted by normal breast epithelium upon progesterone stimulation and increases proliferation of stem/ progenitor cells. Stem Cell Reports 2 780-793. (https://doi. org/10.1016/j.stemcr.2014.05.005)

Lustig B, Jerchow B, Sachs M, Weiler S, Pietsch T, Karsten U, van de Wetering M, Clevers H, Schlag PM, Birchmeier W, et al.2002. Negative feedback loop of Wnt signaling through upregulation of conductin/axin2 in colorectal and liver tumors. Molecular and Cellular Biology 22 1184-1193. (https://doi.org/10.1128/ MCB.22.4.1184-1193.2002)

Lydon J, De MF, Funk C, Mani S, Hughes A, Montgomery CJ, Shyamala G, Conneely O \& O’Malley B 1995. Mice lacking progesterone receptor exhibit pleiotropic reproductive abnormalities. Genes \& Development 9 2266-2278. (https://doi.org/10.1101/ gad.9.18.22660)

Lyons WR 1958. Hormonal synergism in mammary growth. Proceedings of the Royal Society of London. Series B 149 303-325.

MacMahon B, Lin TM, Lowe CR, Mirra AP, Ravnihar B, Salber EJ, Trichopoulos D, Valaoras VG \& Yuasa S 1970. Lactation and cancer of the breast. A summary of an international study. Bulletin of the World Health Organization 42 185-194.

McCormack VA \& dos Santos Silva I 2006. Breast density and parenchymal patterns as markers of breast cancer risk: a metaanalysis. Cancer Epidemiology, Biomarkers \& Prevention 15 1159-1169. (https://doi.org/10.1158/1055-9965.EPI-06-0034) 
Mohammed H, Russell IA, Stark R, Rueda OM, Hickey TE, Tarulli GA, Serandour AA, Birrell SN, Bruna A, Saadi A et al. 2015. Progesterone receptor modulates ERalpha action in breast cancer. Nature $\mathbf{5 2 3}$ 313-317. (https://doi.org/10.1038/nature14583)

Mukherjee A, Soyal SM, Li J, Ying Y, He B, DeMayo FJ \& Lydon JP 2010. Targeting RANKL to a specific subset of murine mammary epithelial cells induces ordered branching morphogenesis and alveologenesis in the absence of progesterone receptor expression. FASEB Journal $\mathbf{2 4}$ 4408-4419. (https://doi.org/10.1096/fj.10-157982)

Mulac-Jericevic B, Mullinax RA, DeMayo FJ, Lydon JP \& Conneely OM 2000. Subgroup of reproductive functions of progesterone mediated by progesterone receptor-B isoform. Science 289 1751-1754. (https:// doi.org/10.1126/science.289.5485.1751)

Mulac-Jericevic B, Lydon JP, DeMayo FJ \& Conneely OM 2003. Defective mammary gland morphogenesis in mice lacking the progesterone receptor B isoform. PNAS 100 9744-9749. (https://doi.org/10.1073/ pnas.1732707100)

Nandi S 1958. Endocrine control of mammary gland development and function in the $\mathrm{C} 3 \mathrm{H} / \mathrm{HeCrgl}$ mouse. Journal of the National Cancer Institute 21 1039-1063.

Nolan E, Vaillant F, Branstetter D, Pal B, Giner G, Whitehead L, Lok SW, Mann GB, Kathleen Cuningham Foundation Consortium for Research into Familial Breast Cancer (kConFab), Rohrbach, K., et al. (2016). RANK ligand as a potential target for breast cancer prevention in BRCA1-mutation carriers. Nature Medicine 22 933-939. (https://doi. org/10.1038/nm.4118)

Nusse R \& Varmus H 1982. Many tumors induced by the mouse mammary tumor virus contain a provirus integrated in the same region of the host genome. Cell 31 p99-109. (https://doi. org/10.1016/0092-8674(82)90409-3)

Pardo I, Lillemoe HA, Blosser RJ, Choi M, Sauder CA, Doxey DK, Mathieson T, Hancock BA, Baptiste D, Atale R et al. 2014. Nextgeneration transcriptome sequencing of the premenopausal breast epithelium using specimens from a normal human breast tissue bank. Breast Cancer Research 16 R26. (https://doi.org/10.1186/ bcr3627)

Pece S, Tosoni D, Confalonieri S, Mazzarol G, Vecchi M, Ronzoni S, Bernard L, Viale G, Pelicci PG \& Di Fiore PP 2010. Biological and molecular heterogeneity of breast cancers correlates with their cancer stem cell content. Cell 140 62-73. (https://doi.org/10.1016/j. cell.2009.12.007)

Piva M, Domenici G, Iriondo O, Rábano M, Simões BM, Comaills V, Barredo I, López-Ruiz JA, Zabalza I, Kypta R et al. 2014. Sox2 promotes tamoxifen resistance in breast cancer cells. EMBO Molecular Medicine 6 66-79. (https://doi.org/10.1002/emmm.201303411)

Rajaram RD, Buric D, Caikovski M, Ayyanan A, Rougemont J, Shan J, Vainio SJ, Yalcin-Ozuysal O \& Brisken C 2015. Progesterone and Wnt4 control mammary stem cells via myoepithelial crosstalk. EMBO Journal 34 641-652. (https://doi.org/10.15252/ embj.201490434)

Reya T \& Clevers H 2005. Wnt signalling in stem cells and cancer. Nature 434 843-850. (https://doi.org/10.1007/s12094-009-0380-4)

Richer JK, Jacobsen BM, Manning NG, Abel MG, Wolf DM \& Horwitz KB 2002. Differential gene regulation by the two progesterone receptor isoforms in human breast cancer cells. Journal of Biological Chemistry 277 5209-5218. (https://doi.org/10.1074/jbc.M110090200)

Riese DJ \& Cullum RL 2014. Epiregulin: roles in normal physiology and cancer. Seminars in Cell and Developmental Biology 28 49-56. (https:// doi.org/10.1016/j.semcdb.2014.03.005)

Russo J, Ao X, Grill C \& Russo IH 1999. Pattern of distribution of cells positive for estrogen receptor alpha and progesterone receptor in relation to proliferating cells in the mammary gland [In Process Citation]. Breast Cancer Research and Treatment 53 217-227. (https:// doi.org/10.1023/A:1006186719322)

Sartorius CA, Melville MY, Hovland AR, Tung L, Takimoto GS \& Horwitz KB 1994. A third transactivation function (AF3) of human progesterone receptors located in the unique N-terminal segment of the B-isoform. Molecular Endocrinology 8 1347-1360. (https://doi. org/10.1210/mend.8.10.7854352)

Seagroves TN, Lydon JP, Hovey RC, Vonderhaar BK \& Rosen JM 2000 C/EBPbeta (CCAAT/enhancer binding protein) controls cell fate determination during mammary gland development. Molecular Endocrinology 14 359-68. (https://doi.org/10.1210/mend.14.3.0434)

Sflomos G, Shamsheddin M \& Brisken C 2015. An ex vivo model to study hormone action in the human breast. Journal of Visualized Experiments e52436. (https://doi.org/10.3791/52436)

Sflomos G, Dormoy V, Metsalu T, Jeitziner R, Battista L, Scabia V, Raffoul W, Delaloye JF, Treboux A \& Fiche M et al. 2016. A preclinical model for ERalpha-positive breast cancer points to the epithelial microenvironment as determinant of luminal phenotype and hormone response. Cancer Cell 29 407-422. (https://doi. org/10.1016/j.ccell.2016.02.002)

Shackleton M, Vaillant F, Simpson KJ, Stingl J, Smyth GK, AsselinLabat ML, Wu L, Lindeman GJ \& Visvader JE 2006. Generation of a functional mammary gland from a single stem cell. Nature $\mathbf{4 3 9}$ 84-88. (https://doi.org/10.1038/nature04372)

Sherman ME, Figueroa JD, Henry JE, Clare SE, Rufenbarger C \& Storniolo AM 2012. The Susan G. Komen for the Cure Tissue Bank at the IU Simon Cancer Center: a unique resource for defining the "molecular histology" of the breast. Cancer Prevention Research 5 528-535. (https://doi.org/10.1158/1940-6207)

Shiah YJ, Tharmapalan P, Casey AE, Joshi PA, McKee TD, Jackson HW, Beristain AG, Chan-Seng-Yue MA, Bader GD \& Lydon JP, et al. 2015 A progesterone-CXCR4 axis controls mammary progenitor cell fate in the adult gland. Stem Cell Reports 4 313-322. (https://doi. org/10.1016/j.stemcr.2015.01.011)

Shyamala G, Yang X, Silberstein G, Barcellos-Hoff MH \& Dale E 1998. Transgenic mice carrying an imbalance in the native ratio of $\mathrm{A}$ to $\mathrm{B}$ forms of progesterone receptor exhibit developmental abnormalities in mammary glands. PNAS 95 696-701. (https://doi.org/10.1073/ pnas.95.2.696)

Singhal H, Greene ME, Tarulli G, Zarnke AL, Bourgo RJ, Laine M, Chang Y-F, Ma S, Dembo AG, Raj GV et al. 2016. Genomic agonism and phenotypic antagonism between estrogen and progesterone receptors in breast cancer. Science Advances 2 e1501924. (https://doi. org/10.1126/sciadv.1501924)

Skiba MA, Bell RJ, Islam RM, Handelsman DJ, Desai R \& Davis SR 2019. Androgens during the reproductive years: what is normal for women? Journal of Clinical Endocrinology and Metabolism 104 5382-5392. (https://doi.org/10.1210/jc.2019-01357)

Sokol ES, Miller DH, Breggia A, Spencer KC, Arendt LM \& Gupta PB 2016. Growth of human breast tissues from patient cells in 3D hydrogel scaffolds. Breast Cancer Research 18 19. (https://doi. org/10.1186/s13058-016-0677-5)

Song W, Wang R, Jiang W, Yin Q, Peng G, Yang R, Yu QC, Chen J, Li J, Cheung $\mathrm{H}$ et al. 2019. Hormones induce the formation of luminalderived basal cells in the mammary gland. Cell Research 29 206-220. (https://doi.org/10.1038/s41422-018-0137-0)

Soto AM \& Sonnenschein C 2015. Endocrine disruptors: DDT, endocrine disruption and breast cancer. Nature Reviews Endocrinology 11 507-508. (https://doi.org/10.1038/nrendo.2015.125)

Soto AM, Brisken C, Schaeberle C \& Sonnenschein C 2013. Does cancer start in the womb? altered mammary gland development and predisposition to breast cancer due to in utero exposure to endocrine disruptors. Journal of Mammary Gland Biology and Neoplasia 18 199-208. (https://doi.org/10.1007/s10911-013-9293-5)

Stampfer MR \& Bartley JC 1985. Induction of transformation and continuous cell lines from normal human mammary epithelial cells after exposure to benzo[a]pyrene. PNAS 82 2394-2398. (https://doi. org/10.1073/pnas.82.8.2394)

Stingl J, Eirew P, Ricketson I, Shackleton M, Vaillant F, Choi D, Li HI \& Eaves CJ 2006. Purification and unique properties of mammary 
epithelial stem cells. Nature 439 993-997. (https://doi.org/10.1038/ nature04496)

Tanos T, Sflomos G,Echeverria PC, Ayyanan A, Gutierrez M, Delaloye JF, Raffoul W,Fiche M, Dougall W, Schneider P, Yalcin-Ozuysal O, Brisken C 2013. Progesterone/RANKL is a major regulatory axis in the human breast. Science Translational Medicine 5 1-10. (https://doi. org/10.1126/scitranslmed.3005654)

Tsukamoto A, Grosschedl R, Guzman R, Parslow T \& Varmus H 1988. Expression of the int-1 gene in transgenic mice is associated with mammary gland hyperplasia and adenocarcinomas in male and female mice. Cell 55 619-625. (https://doi.org/10.1016/00928674(88)90220-60)

Vachon CM, Sellers TA, Vierkant RA, Wu FF \& Brandt KR 2002. Casecontrol study of increased mammographic breast density response to hormone replacement therapy. Cancer Epidemiology, Biomarkers \& Prevention 11 1382-1388.

Van Keymeulen A, Rocha AS, Ousset M, Beck B, Bouvencourt G, Rock J, Sharma N, Dekoninck S \& Blanpain C 2011. Distinct stem cells contribute to mammary gland development and maintenance. Nature 479 189-193. (https://doi.org/10.1038/ nature10573)

Van Keymeulen A, Fioramonti M, Centonze A, Bouvencourt G, Achouri Y \& Blanpain C 2017. Lineage-restricted mammary stem cells sustain the development, homeostasis, and regeneration of the estrogen receptor positive lineage. Cell Reports 20 1525-1532. (https://doi.org/10.1016/j.celrep.2017.07.066)

Veltmaat JM 2017. Prenatal mammary gland development in the mouse: research models and techniques for its study from past to present. Methods in Molecular Biology 1501 21-76. (https://doi. org/10.1007/978-1-4939-6475-8_2)

Vogel PM, Georgiade NG, Fetter BF, Vogel FS \& McCarty KS 1981. The correlation of histologic changes in the human breast with the menstrual cycle. American Journal of Pathology 104 23-34.

Wang S, Counterman LJ \& Haslam SZ 1990. Progesterone action in normal mouse mammary gland. Endocrinology 127 2183-2189. (https://doi.org/10.1210/endo-127-5-2183)

Received in final form 28 May 2020

Accepted 5 June 2020

Accepted Manuscript published online 5 June 2020
(C) 2020 Society for Endocrinology Published by Bioscientifica Ltd. Printed in Great Britain 